\title{
ISTRAŽIVANJE PRAKSE HRVATSKIH PODUZEĆA U RAZVOJU I UPRAVLJANJU MARKOM POSLOVNE USLUGE ${ }^{1}$
}

Rad izučava temu razvoja i upravljanja markama poslovnih usluga. Nakon pregleda teorijskog dijela, u radu se predstavljaju rezultati primarnog istraživanja. Cilj je istraživanja utvrditi na koji način hrvatska poduzeća razvijaju svoju marku usluga, kako njome upravljaju, kako prenose informacije o njoj i na koji je način vrednuju. Provedeno je jednokratno krossekcijsko istraživanje na prigodnom uzorku poduzeća koja pružaju različite poslovne usluge. Rezultati pokazuju kako se analizirana poduzeća prema marki svoje usluge odnose kao prema vrijednoj nematerijalnoj imovini, primjenjuju holistički pristup izgradnje marke te najčešće primjenjuju strategiju korporativne marke. Neodvojivost usluge od zaposlenika rezultira time da su hrvatska poduzeća više usmjerena na interno nego na eksterno komuniciranje. S obzirom na to da je istraživanje razvoja i upravljanja markama usluga na poslovnim tržištima manje istraženo u odnosu na tržište krajnje potrošnje, rad pridonosi novim spoznajama u ovom području. Osim toga, zaključci temeljeni na istraživanju predstavljaju vrijednu spoznaju za poduzeća koja žele aktivno upravljati svojom markom poslovne usluge.

* D. Sinčić Ćorić, dr.sc., redovita profesorica, Sveučilište u Zagrebu, Ekonomski fakultet (email: dsincic@efzg.hr).

** L. Babić, mag. oec. (e-mail: dubravacl@gmail.com). Rad je primljen u uredništvo 19.11.2020. godine, a prihvaćen je za objavu 12.02.2021. godine.

1 Podaci analizirani u radu prikupljeni su za potrebe diplomskoga rada „Razvoj i upravljanje markom usluge na poslovnim tržištima“" studentice Lucije Babić, izrađenog pod mentorstvom prof. dr. sc. Dubravke Sinčić Ćorić 
Ključne riječi: marka poslovne usluge, poslovna tržišta, identitet marke usluge, vrijednost marke usluge, korporativna marka

\section{UVOD}

Poslovne usluge, kao što su istraživanje tržišta, revizija te marketinško, pravno, porezno ili financijsko savjetovanje, sve se više prepoznaju kao strateški važne, zato što poduzećima mogu osigurati prijenos znanja i tehnologije, smanjiti troškove i potaknuti inovacije. Njihova važnost vidljiva je iz činjenice da potrošnja na poslovne usluge kontinuirano raste. Prema procjenama, čak do 50\% proračuna poduzeća troši se na poslovne usluge (Bals, Hartmann i Ritter, 2009; Pemer, Werr i Bianchi, 2014). Dodatno, sve jača konkurencija u različitim poslovnim (engl. $b u$ siness-to-business, B2B) uslužnim djelatnostima navela je menadžere da teže. postizanju konkurentske prednosti razvijanjem marke svoje usluge, kao što to čine mnoga poduzeća koja posluju na tržištima krajnje potrošnje (engl. business-toconsumer, B2C) (Guenther i Guenther, 2019).

Poslovne usluge usko su vezane uz iskustvo korisnika, kojima je nerijetko teško ocijeniti kvalitetu usluge, čak i nakon što je ona isporučena (Sharp, 1996). Percepcija kvalitete poslovnih usluga izravno je povezana s percepcijom stručnosti ponuđača i zadovoljstvom interakcije u procesu pružanja usluge. Stoga poduzeća čije se poslovanje temelji na pružanju usluga trebaju pažljivo definirati jedinstvene prednosti kako bi pozicionirala svoju marku usluga.

Marka je ime, pojam, znak, simbol, dizajn ili kombinacija ovih elemenata, namijenjena prepoznavanju ili diferenciranju funkcionalnih ili psiholoških koristi proizvoda i usluga jednog ponuđača ili skupine ponuđača od konkurencije (Kotler i Pfoertsch, 2006; Grbac, 2007; Vranešević, 2007). Keller (2013) navodi kako marka poduzeću predstavlja sredstvo identificiranja za jednostavnije rukovanje i praćenje, sredstvo pravne zaštite jedinstvenih obilježja, izvor konkurentskih prednosti i izvor financijskih prihoda, dok kupcima i klijentima omogućuje identificiranje podrijetla proizvoda, određivanje odgovornosti proizvođača, smanjivanje rizika, smanjivanje troškova traženja proizvoda, obećanje, jamstvo ili ugovor s proizvođačem, simboličko sredstvo i znak kvalitete. Kotler i Pfoertsch (2006) ističu da uslijed rasta konkurencije raste i cjenovni pritisak na poduzeća, a upravo marka može diferencirati poduzeće i predstavljati dodatnu vrijednost, prenoseći opipljive i neopipljive elemente ponude. Dodatno, marke na poslovnim tržištima nemaju za cilj doprijeti samo do kupca, nego do svih sudionika na poslovnim tržištima - investitora, zaposlenika, partnera, dobavljača, konkurenata, zakonodavnih tijela te lokalne zajednice. 
Kako navode Bendixen, Bukasa i Abratt (2004) te Kotler i Pfoertsch (2007), marka je glavni oslonac u procesu donošenja odluke o kupnji na poslovnim tržištima, a posebno kada su u pitanju usluge, koje su neopipljive i rizičnije (Kim i Hyun, 2011; Biedenbach i Marell, 2010, prema Zang, Jiang, Shabbir i Zhu, 2016).

U usporedbi s istraživanjem razvoja i upravljanja markama usluga na tržištu krajnje potrošnje, primjetno je kako je takvih istraživanja na poslovnim tržištima manje. Taj istraživački jaz postoji iz više razloga. Razvoj marke na poslovnom tržištu dugo se vremena povezivao samo s industrijskim proizvodima, poput komponenata, sastavnih dijelova, kemikalija ili postrojenja, dok je područje razvoja marke poslovnih usluga dugo bilo zapostavljano. Ovaj rad pridonosi smanjenju istraživačkog jaza analizom specifičnosti razvoja i upravljanja markom poslovnih usluga poduzeća koja posluju na tržištu Republike Hrvatske. Rad je organiziran tako da, nakon pregleda osnovnih teorijskih koncepata, predstavlja rezultate empirijskog istraživanja provedenog na poduzećima iz Republike Hrvatske koja pružaju usluge poslovnim korisnicima. Rad završava raspravom i zaključnim razmatranjima.

\section{TEORIJSKI OKVIR}

\subsection{Razvoj marke poslovne usluge}

Razvoj marke uključuje definiranje identiteta marke, stvaranje njenog značenja, pronalaženje primjerenog odgovora marke i uspostavljanje odgovarajućeg odnosa marke i korisnika (Keller, 2001, prema Kotler i Pfoertsch, 2006).

Prilikom razvoja marke na tržištu poslovne potrošnje, poduzeća trebaju imati na umu (1) da je marka dugoročna imovina koja tijekom vremena akumulira značenje za kupca i donosi dobit nakon što joj kupci počnu vjerovati, (2) da dvije dimenzije centralizacije/decentralizacije te standardiziranosti/prilagođenosti ponude omogućuju poduzećima arhitekturu marke koja je optimalna za različite kontekste poslovanja na poslovnim tržištima i (3) da skladne kolekcije dobro pozicioniranih marki služe kao snažna konkurentska prednost na tržištu (Muylle, Dawar i Rangarajan 2012).

Strategija razvoja marke temelji se na definiranom pozicioniranju marke, njezinoj misiji, vrijednosti, obećanju koje daje i arhitekturi marke. Arhitektura marke predstavlja skup marki poduzeća i njihove međusobne odnose pa tako različite strategije marke zahtijevaju i različitu arhitekturu. U literaturi se kao najčešće navode dva tipa arhitekture marke: (1) arhitektura „markirane kuće“ (engl. branded 
house architecture), koja se temelji na principu jedne krovne marke koja obuhvaća niz ponuda pod-marki i (2) arhitektura „kuća marki“ (engl. house of brands architecture), koja pretpostavlja da je svaka marka samostalna, a zbroj rezultata svih samostalnih marki veći je od rezultata svake pojedinačne marke (Kotler i Pfoertsch, 2006).

Muylle, Dawar i Rangarajan (2012) predstavili su model arhitekture marke koji proizlazi iz pet faza u razvoju odnosa korisnika i ponuđača. Ideja njihovog pristupa je da se arhitektura marke može dizajnirati tako da utječe na smanjenje korisničkog rizika u svakoj pojedinoj fazi izgradnje odnosa i pokazuje kako svaka razina arhitekture marke odgovara na različite rizike korisnika u pojedinoj fazi.

Berry je razvio model izgradnje marke usluga koji se temelji na činjenici da je razvoj marke ključan u uslužnom sektoru zbog toga što usluge nemaju fizički oblik te je poduzeće primarno važna marka (Berry, 2000, prema Marquardt, Golicic i Davis, 2011). Prema ovome modelu, izgradnja marke usluga sastoji se od pet elemenata identiteta marke: vanjske komunikacije marke, iskustva klijenta, osviještenosti o marki, značenja marke i vrijednosti marke.

Istraživanje koje su proveli Marquardt, Golicic i Davis (2011) ukazuje na to da se izgradnja marke usluga na poslovnim tržištima sastoji od tri dijela upravljanja markom: razvijanje uvjerljivog prijedloga vrijednosti marke, interne i eksterne komunikacije $\mathrm{i}$ iskustva kupaca s markom.

Vizualni i fizički elementi koji služe identificiranju i diferenciranju proizvoda ili usluge (Kotler i Pfoertsch, 2006) predstavljaju determinante marke. Kada je riječ o markama usluga, ključne determinante uspjeha su klijenti, financije i zaposlenici (Coleman, de Chernatony i Christodoulides, 2011). Determinante marke trebaju biti definirane tako da maksimalno umanje mogućnost njezinog slabljenja (Keller, 2003.). Za izgradnju snažne marke ključni su sljedeći elementi: ime marke, znak (logotip), tagline ili slogan i priča marke (Kotler i Pfoertsch, 2006).

Ime marke svojevrsno je prvo „lice“ marke i njezina najveća ekspresija. Uobičajeno je da ime marke ima ulogu asociranja, odnosno da odašilje određenu poruku, stoga je iznimno važno ime pažljivo izabrati (Kotler i Pfoertsch, 2006). Ovo posebno dolazi do izražaja kod marki koje posluju na globalnom tržištu na kojem se susreću s različitim kulturama, običajima, mentalitetom, poslovnom kulturom pa i različitim tumačenjima istih pojmova.

Znak marke (logotip) grafički je izraz imena marke ili tvrtke. Dobar logotip zadovoljava oba imperativa, grafički i funkcionalni, a da bi se to postiglo važno je prilikom dizajniranja logotipa imati na umu vrijednosti i karakteristike poduzeća. Dobro odabrana kombinacija svih vizualnih elemenata može značajno povećati razinu prepoznatljivosti marke (Kotler i Pfoertsch, 2006). 
Tagline ili slogan lako je prepoznatljiva i pamtljiva fraza. Glavna je svrha slogana poduprijeti imidž marke projiciran njezinim imenom i logotipom. U kreiranju identiteta marke, slogan ima jedinstvenu ulogu u stvaranju skladnog identiteta i koristi se u oglašavanju i drugim oblicima komunikacije (Kotler i Pfoertsch, 2006).

Priča marke zaposlenicima daje jasnu ideju o tome koje su njezine vrijednosti, dok kupci mogu vidjeti koje obećanje marka daje. Prava snaga dobre priče marke je u dubini, vjerodostojnosti i jasnoći poruke koja se šalje svim dionicima, stoga priča o marki treba dati jasnu i relevantnu sliku o kakvom se poslu radi (Fog, 2005, prema Kotler i Pfoertsch, 2006).

Svi elementi marke kojima se ona predstavlja ciljnoj skupini čine jedinstven skup asocijacija koji predstavlja ono što marka zastupa i obećava, odnosno njezin identitet. Snažan identitet marke važan je čimbenik korporativnog uspjeha na poslovnim tržištima (Baumgarth i Schmidt, 2010). Zbog nematerijalnosti usluga, vizualni elementi pomažu korisnicima prilikom procjene usluga i prenose identitet marke, stoga bi uslužna poduzeća trebala osigurati da svi vizualni elementi prenose takve informacije (Coleman i suradnici, 2011).

Interpretacija odnosno percepcija elemenata identiteta marke predstavlja imidž marke. Osnovna je razlika između identiteta marke i njezinog imidža ta što je imidž marke sadržan u svijesti korisnika, odnosno imidž je skup percepcija korisnika o marki. Identitet marke nalazi se na strani pošiljatelja, dok se imidž nalazi na strani primatelja poruke. Dvostruki koncept identiteta marke (imidž marke koji se želi stvoriti ili održati) i njezinog pozicioniranja (dio identiteta o kojem treba aktivno prenositi informacije) ima ključnu ulogu u upravljanju markom (Aaker, Kumar, Dej, 2008).

Coleman i suradnici (2011) daju kritički osvrt na postojeće okvire identiteta marke i predlažu mrežu identiteta marke usluga koja proizlazi iz korporativnih, organizacijskih i literarnih identiteta marke, kako bi se objedinile informacije o identitetu marke i dimenzionirao identitet marke usluga (Sammy, Omwenga i Iravo, 2016). Mreža identiteta marke usluga predstavlja identitet marke kroz holističku i integriranu konstrukciju vođenu simbolikom veza i međusobnih interakcija između osobnosti marke, korporativnog vizualnog identiteta, dosljedne komunikacije, inicijativa usmjerenih prema ljudskim resursima i fokusa na zaposlenike i korisnike. Dosljedno prenošenje informacija o dimenzijama ove mreže identiteta podrazumijeva poznavanje marketinških komunikacijskih alata i sposobnost njihova korištenja s ciljem dosljednog razvoja identiteta marke (Sammy i suradnici, 2016). Ono što vodeće svjetske marke na poslovnim tržištima imaju zajedničko je da se njihov identitet temelji na prilagođavanju i pružanju sveobuhvatnog rješenja problema organizacijskim kupcima (Beverland i suradnici, 2007), stoga je za uspjeh marke usluge na poslovnom tržištu potrebno identitet marke graditi upravo oko tih karakteristika. 
Uslužna poduzeća koja posluju na tržištima poslovne potrošnje, a koja imaju jak i pozitivan identitet marke, neizbježno će zadržati snažnu i povoljnu poziciju na tržištu, što vodi do pronalaska novih korisnika (Davis, Golic i Marquardt, 2008; Kumar, Cohen i Rajan, 2015, prema Vester, Petzer i Cunningham, 2019). Kako bi postigle jak i poželjan identitet marke usluge na tržištima poslovne potrošnje, poduzeća bi trebala osigurati provedbu svih pet dimenzija mreže identiteta marke usluga koje čine koncept identiteta marke (Coleman i suradnici, 2011).

\subsection{Upravljanje markom poslovne usluge}

Upravljanje markom utječe na njezinu vrijednost i predstavlja trud poduzeća da izgradi i ovjekovječi snažnu marku (Marquardt, Golicic i Davis, 2011). Upravljanje markom usluga na poslovnim tržištima može se opisati kroz tri aktivnosti: izgradnja jedinstvene vrijednosti marke, upravljanje internom i vanjskom komunikacijom te osiguranje pozitivnog iskustva korisnika s markom.

\subsubsection{Alati izgradnje marke poslovne usluge}

Alati izgradnje marke sredstva su marketinške komunikacije koja poduzeća koriste kako bi informirala, uvjeravala i podsjećala kupce, izravno ili neizravno, o svojim markama.

Iako najskuplja, osobna prodaja osnovni je pokretač izgradnje dugoročnih poslovnih odnosa koji se temelje na bliskim osobnim interakcijama i činjenici da prodajni predstavnici dobro poznaju proizvode i tržišta (Vitale i Giglierano, 2002, prema Kotler i Pfoertsch, 2006). Bez obzira na to što je internet drastično utjecao na promjene komunikacijske strategije u različitim industrijama, osobna prodaja i dalje je dominanta prodajna i komunikacijska strategija na tržištima poslovne potrošnje (Deeter-Schmelz i Kennedy, 2004, prema Baumgarth i Schmidt, 2010.). Binckebanck (2006) ističe kako su osobnost prodajnog osoblja i priroda odnosa važniji od karakteristika samog proizvoda ili usluge i sadržaja neosobne marketinške komunikacije u stvaranju vrijednosti marke na tržištima poslovne potrošnje (Baumgarth i Schmidt, 2010). Istraživanje provedeno na izvršnim menadžerima njemačkih poduzeća koja posluju na poslovnim tržištima pokazuje kako mišljenje menadžera o osobnosti i ponašanju prodajnog osoblja izravno utječe na njihovu percepciju marke (Baumgarth i Binckebanck, 2011, prema Biedenbach, Hulten i Tarnovskaya, 2019). 
Iako se izgradnja marke na poslovnim tržištima uglavnom oslanja na osobnu prodaju, holistički pristup izgradnji marke znači da su svi elementi važni zato što neki služe za povećanje upoznatosti s markom, neki za poticanje željenih akcija i asocijacija, za izazivanje pozitivnih emocija ili pak za izgradnju snažnije veze korisnika i marke (Kotler i Keller, 2006, prema Kotler i Pfoertsch, 2006). Stoga izgradnja marke u doba digitalne komunikacije zahtjeva jaku internu, kao i dosljednu eksternu komunikaciju, ali i pozicioniranje marke u razgovorima o aktualnim temama kako bi postala vođa javnog mnijenja (Lipiainen i Karjaluoto, 2015). Kako je tijekom vremena broj dodirnih točaka marke i zainteresiranih sudionika porastao, poduzeća moraju obratiti pozornost na dosljednost komunikacije u digitalnim i tradicionalnim kanalima (Helm i Jones, 2010, prema Lipiainen, i Karjaluoto, 2015). Primjerice, kako ističu Diba, Vella i Abratt (2019), profesionalci se na LinkedInu međusobno povezuju, razgovaraju, uspostavljaju odnose te se povezuju s markama u svojoj industriji kako bi dijelili profesionalni sadržaj.

S obzirom na to da su usluge neopipljive, poduzeća koja se bave pružanjem usluga nerijetko svoj identitet marke grade na kvaliteti usluge, ugledu tvrtke, vještinama, ljubaznosti i profesionalnosti osoblja, što dodatno pojačavaju akreditacijskim certifikatima kao što su ISO certifikati, usporednim analizama industrije koje provode vanjska tijela i izjavama zadovoljnih korisnika (Beverland, Napoli i Yakimova, 2007). Na tržištima poslovne potrošnje preporuke se temelje na jednostavnom pravilu, a to je da odlično iskustvo korisnika može pokrenuti komentiranje. Koliko je važna i koliko snažna može biti preporuka, najbolje potvrđuju primjeri iz industrija koja imaju zakonska ograničenja u oglašavanju, kao što je to slučaj s odvjetnicima i liječnicima (Kotler i Pfoertsch, 2006). Iskustvo korisnika prenosi se i komunikacijom od usta do usta, koja na poslovnim tržištima može imati ključan utjecaj na odluku o kupnji, i to zbog karakteristika usluga: neopipljivosti, nemogućnosti odjeljivanja proizvodnje od korištenja, ali i nestandardiziranosti.

\subsubsection{Interno prenošenje informacija o marki poslovne usluge (Interna komunikacija)}

Za uspjeh marke ključno je učinkovito interno prenositi informacije o njezinim vrijednostima i to na način da zaposlenici razumiju te vrijednosti i da postanu najbolji ambasadori poduzeća i njegovih marki (Kotler i Pfoertsch, 2006). Kad je riječ o marki usluge, izazovi izgradnje marke još su veći zato što je osnova poslovanja ljudski kapital, koji se definira kao osobno znanje, vještine i mogućnosti pojedinca, pa to zapravo znači da znanje posjeduju zaposlenici, a ne poduzeće (Widener, 2004, prema Biedenbach, Hulten i Tarnovkaya, 2019). Istraživanja su pokazala kako zaposle- 
nici pružatelja usluga imaju važan utjecaj na to kako će klijenti ocijeniti uslugu, što uključuje verbalnu i neverbalnu komunikaciju zaposlenika, njihovu prilagodljivost, orijentiranost na klijenta, zadovoljstvo zaposlenika i percepciju korisnika o tome koliko se zaposlenik trudi (više o tome u Baumgarth i Schmidt, 2010).

Lynch i de Chernatony (2004) navode kako je za uspješnu internu izgradnju marke važno uskladiti njezina tri unutarnja kanala: organizacijsku kulturu, medije interne komunikacije i treninge. Cilj je interne izgradnje marke prenositi informacije o marki zaposlenicima kako bi njihov mentalni sklop bio usklađen s poslovnom strategijom i kako bi isporučivali vrijednosti marke u svakoj fazi svog svakodnevnog rada. Interna predanost marki može se tumačiti kao psihološka veza zaposlenika i marke koja predstavlja volju zaposlenika da se ponaša na način koji je usklađen s markom i da uloži dodatni napor kako bi se postigli ciljevi strategije marke (Burmann, Zepelin i Riley, 2009, prema Baumgarth i Schmidt, 2010.). Biedenbach i suradnici (2019) navode kako u kampanjama privlačenja novih zaposlenika uslužna poduzeća trebaju naglašavati što od njih očekuju, ali isto tako i koliko ulažu u razvoj kompetencija zaposlenika tijekom njihove karijere.

Na pitanje što marku čini uspješnom, Kotler i Pfoertsch (2006) odgovaraju da je marku potrebno inkorporirati u unutarnje procese, odnosno da izgradnja marke treba započeti unutar poduzeća. Uloga zaposlenika neodvojiva je od same marke zato što upravo zaposlenici čine marku živom i predstavljaju sve što ona jest. Uslugu čine sami zaposlenici i zato Coleman i suradnici (2011) u svojoj mreži identiteta marke usluge navode inicijative ljudskih resursa usredotočene na nadzor rada zaposlenika i treninge koji zaposlenicima omogućuju produbljivanje veze s korisnicima. Istraživanja su pokazala kako postoji pozitivna i čvrsta veza između pristupa poduzeća formalnim i neformalnim obukama zaposlenika i pružanja usluge (Tan i Lim, 2012, prema Sammy, Omwenga i Iravo, 2016). Biedenbach i suradnici (2019) pokazali su kako su ljudski kapital i povjerenje u odnosu važni za vrijednost marke, a posebno kada su u pitanju usluge kod kojih ljudski kapital ima izravan utjecaj na povjerenje u marku, percipiranu kvalitetu i odanost marki. Pored toga, za očekivati je da na odnos temeljen na povjerenju koje je korisnik razvio prema pružatelju usluge utječe njegova percepcija o vještinama i nastojanjima pružatelja usluge da kvalitetno obavi poslove koji su korisniku važni (Biedenbach, Hulten i Tarnovskaya, 2019).

\subsubsection{Eksterno prenošenje informacija o marki poslovne usluge (Eksterna komunikacija)}

Prema Kotleru i Pfoertschu (2006), marka se izgrađuje kroz svaku pojedinu dodirnu točku kupca i marke, bila ona izravna ili neizravna, a ne samo kroz 
marketinške inicijative. Svaka dodirna točka kupca s markom zapravo je iskustvo korisnika koje mu prenosi određene informacije, što pak znači da poduzeća trebaju dano obećanje ispunjavati dosljedno, iznova i u svakoj pojedinoj dodirnoj točki.

Specifičnost poslovnog tržišta su tzv. kupovni centri. Kupovni centar uobičajeno čine pojedinci koji sudjeluju u procesu donošenja odluka i imaju različite uloge - jedni su korisnici, drugi donose odluke i na njih utječu, a treći realiziraju kupnju ili mogu utjecati na tijek informacija (Sinčić, 2004; Tomašević Lišanin i suradnici, 2019.). Da bi se shvatio proces donošenja odluke, važno je poznavati strukturu kupovnog centra kao i kriterije na temelju kojih se donosi odluka. Istražujući stilove odlučivanja u kupnji proizvodnih poduzeća, Sinčić Ćorić, Anić, Piri Rajh, Rajh i Kurnoga (2017) došli su do zaključka da postoje četiri klastera kupaca: mudri kupci, ad hoc kupci, centralizirani kupci i ekonomični kupci. Prema njihovu istraživanju, mudri kupci najveću pozornost pri odluci o odabiru dobavljača poklanjaju upravo njegovoj pouzdanosti, što implicira prepoznavanje važnosti ove karakteristike kao odrednice marke dobavljača. Leek i Christodoulides (2011) navode kako se marka proizvoda ili usluge na poslovnim tržištima koristi kao kriterij ocjenjivanja prilikom biranja dobavljača i to prema percipiranoj kvaliteti marke. Mudambi (2002) kupce na poslovnim tržištima svrstava u tri klastera, i to na temelju kriterija koliko su pojedine osobe koje čine kupovni centar osjetljive na marku, odnosno prema tome kako percipiraju njezinu važnost, te zaključuje da je marka nešto što nije jednako važno svim jedinicama kupovnog centra, osim u situaciji složene kupovne odluke. Leek i Christodoulides (2011) slažu se da važnost marke raste proporcionalno s kompleksnošću odluke i percipiranom riziku nabave proizvoda ili usluge.

\subsubsection{Uloga korporativne marke}

Korporativna marka na poslovnim tržištima odnosi se na specifičnu percepciju marke koju korisnici najčešće procjenjuju i vrednuju i koja utječe na njihovu odluku o kupnji. Na tržištima poslovne potrošnje, osobe zadužene za marketing najčešće naglašavaju korporativnu marku pri čemu je samo ime tvrtke najčešće i marka (Gomes, Fernandes i Brandão, 2016). Korporativna marka najviše se koristi upravo na tržištima poslovnih usluga (Roberts i Merrilees, 2007), ali i na tržištima poslovne potrošnje zato što su promjene na poslovnim tržištima toliko brze da korporativna marka služi kako bi se izgradilo nešto konstantno i dugotrajno (Kotler i Pfoertsch, 2006). Usluge podrazumijevaju interakciju između korisnika i ponuđača pa prilagodba usluge, odnos i ekspertiza imaju glavnu ulogu (Aspara i Tikkanen, 2008). Neopipljivost usluga može biti uzrok nesigurnosti i upravo jake 
marke mogu pomoći pri rješavanju takve nesigurnosti (Brown i suradnici, 2012., prema Gomes, Fernandes i Brandão, 2016.).

Korporativna marka ne odražava samo identitet poduzeća, nego služi i kao marka odnosa na temelju veličine i prestiža prethodnih korisnika, povijesti izvedbe i cjelokupne aktivnosti organizacije (Bengtsson i suradnici, 2005; Blomback i Axelsson, 2007; Gomes, Fernandes i Brandão, 2016). Imidž korporativne marke u početnoj fazi traženja ponuđača može imati i funkciju svojevrsnog kriterija eliminacije, što najviše dolazi do izražaja kada su u pitanju usluge i atributi usluga koje je teško ocijeniti (Blomback i Axelsson, 2007; Srivastava i Sharma, 2013). Stoga razvoju korporativne marke na poslovnom tržištu treba pristupiti odgovorno, osobito uzme li se u obzir da pozitivan imidž korporativne marke povoljno utječe na ostvarivanje premijskih cijena i zadržavanje vrijednosti marke (Balmer, Lin, Chen i He, 2020).

Kupci na poslovnim tržištima najčešće traže partnera za dugoročnu suradnju pa zbog toga uloga korporativne marke može biti ključna u procesu donošenja odluke o kupnji (Gomes, Fernandes i Brandão, 2016).

\section{ISTRAŽIVANJE PRAKSE HRVATSKIH PODUZEĆA U RAZVOJU I UPRAVLJANJU MARKOM POSLOVNE USLUGE}

\subsection{Cilj istraživanja $i$ istraživačka pitanja}

Cilj je empirijskog dijela rada istražiti na koji način hrvatska poduzeća razvijaju svoju marku usluge, kako njome upravljaju, kako o njoj prenose informacije i na koji je način vrednuju.

Sukladno cilju rada, identificirana su tri glavna istraživačka pitanja:

P1. Jesu li hrvatska poduzeća koja pružaju poslovne usluge usmjerene na izgradnju marke usluge?

P2. Prenose li hrvatska poduzeća koja pružaju poslovne usluge informacije o svojoj marki usluge zaposlenicima?

P3. Vode li hrvatska poduzeća koja pružaju poslovne usluge računa o dosljednosti prilikom prenošenja informacija o svojoj marki usluge? 


\subsection{Metodologija istraživanja}

Za potrebe istraživanja praksi hrvatskih poduzeća u razvoju i upravljanju markom poslovnih usluga, provedeno je jednokratno kros-sekcijsko istraživanje na prigodnom uzorku poduzeća koja pružaju različite poslovne usluge. Ispitanici su zaposlenici zaduženi za marketing, odnosno za razvoj strategije marke usluge, odabrani pomoću društvene mreže LinkedIn.

Kao okvir istraživanja korišteno je istraživanje iz 2011. godine koje su proveli Marquardt, Golicic i Davis, a koje je pokazalo kako uslužne tvrtke trebaju stvoriti posebno i jedinstveno iskustvo koje korisnik može vezati uz uslugu. Istraživanje koje su 2019. godine proveli Biedenbach, Hulten i Tarnovskaya ukazuje na to da ljudski kapital ima veći utjecaj na vrijednost marke usluge nego što ga ima povjerenje u poduzeće koje pruža uslugu na poslovnom tržištu. Dodatno, kao okvir istraživanja korišteno je i istraživanje Zhanga, Jianga, Shabbira i Zhua iz 2016. godine koje je pokazalo kako poduzeća orijentirana na izgradnju marke usluge aktivno prenose informacije o svojoj marki izvan poduzeća i unutar njega te da to pozitivno utječe na izgradnju korporativne marke.

Sva pitanja u anketi bila su zatvorenog tipa i podijeljena u četiri kategorije sukladno predmetu i ciljevima istraživanja. Prva skupina pitanja odnosi se na orijentiranost poduzeća na izgradnju marke usluge i služi za identificiranje praksi hrvatskih poduzeća u upravljanju markom usluge. Druga skupina obuhvaća pitanja o internoj komunikaciji poduzeća o marki, kako bi se identificirala uloga i važnost zaposlenika u izgradnji marke usluge. Treća skupina pitanja odnosi se na eksternu komunikaciju, s ciljem identificiranja determinanti i alata koja poduzeća koriste $\mathrm{u}$ prenošenju marke svoje usluge vanjskoj javnosti. Posljednja skupina pitanja sadrži pitanja o prirodi poslovanja poduzeća. Upitnik ukupno ima 23 pitanja na koja su ispitanici odgovarali odabirom jednog od pet stupnjeva Likertove skale, unosili točan iznos pokazatelja ili birali između više ponuđenih odgovora.

Anketa se provodila elektroničkim putem u srpnju 2020. godine. Populacija istraživanja obuhvaćala je poduzeća koja pružaju poslovne usluge na tržištu Republike Hrvatske. Uzorak od 59 ispitanika, odnosno 59 poduzeća, uključivao je zaposlenike zadužene za razvoj strategije marketinga usluga, a odabran je pomoću društvene mreže LinkedIn. Demografske i geografske karakteristike samih ispitanika nisu relevantne za ovo istraživanje, stoga nisu ni uzete u obzir. 


\subsection{Rezultati istraživanja}

Poziv na sudjelovanje u istraživanju upućen je uzorku od 59 ispitanika, što je rezultiralo s 37 uspješno ispunjenih anketa, odnosno stopom odgovora od 63\%. Od 37 uspješno ispunjenih anketa, sve su sadržavale odgovore na sva pitanja te je za konačnu analizu prikupljeno 37 valjanih upitnika.

\subsubsection{Opis uzorka}

S obzirom na segment usluga u kojem poduzeća čiji su zaposlenici sudjelovali u istraživanju posluju, 46\% (17) ispitanika radi u poduzećima koja pružaju usluge promidžbe i istraživanja tržišta, odnosno marketinške usluge. Drugi značajni segment ispitanika zaposlen je u poduzećima koja se bave računalnim programiranjem i savjetovanjem te čine 30\% (11) ispitanika. Struktura uzorka prikazana je na grafu 1.

Graf 1.

DISTRIBUCIJA ISPITANIKA PREMA SEGMENTU USLUGA NA POSLOVNOM TRŽIŠTU

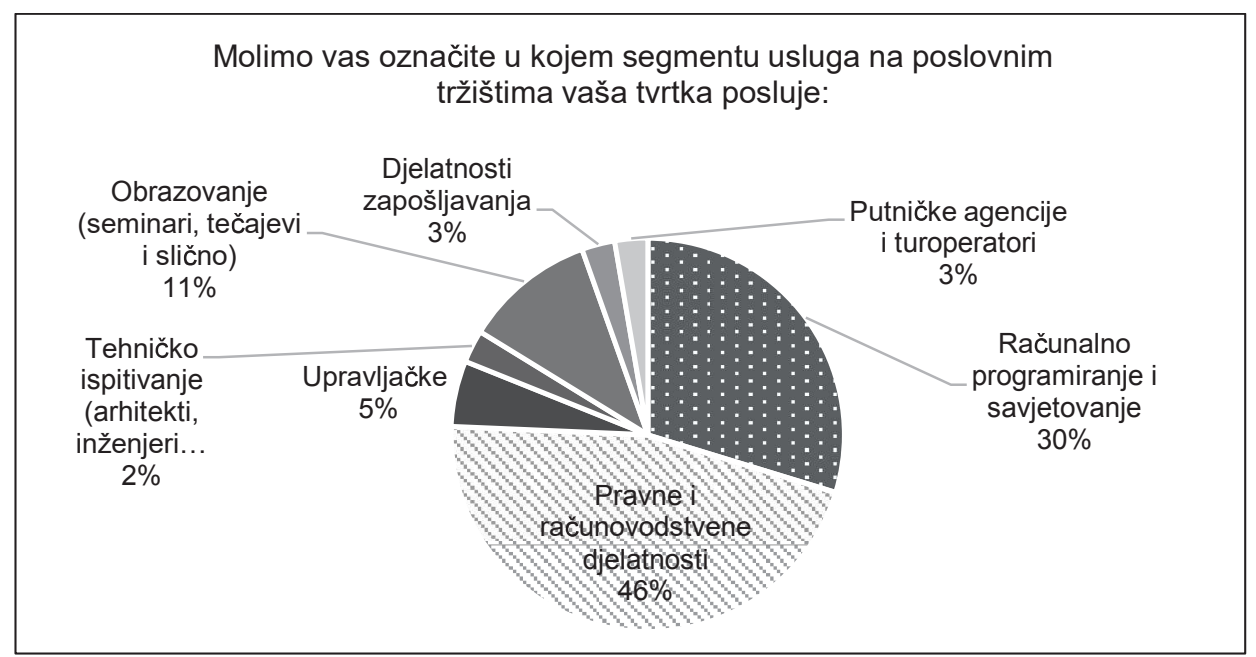

Izvor: Istraživanje 
Analiza veličine poduzeća čiji su zaposlenici sudjelovali u istraživanju pokazuje kako su $84 \%$ (31) mala poduzeća, odnosno imaju manje od 50 zaposlenika. Od toga, 49\% (18) poduzeća čiji su zaposlenici sudjelovali u istraživanju ima manje od 10 zaposlenika, što je prikazano na grafu 2.

Graf 2.

DISTRIBUCIJA ISPITANIH PODUZEĆA PREMA BROJU ZAPOSLENIKA

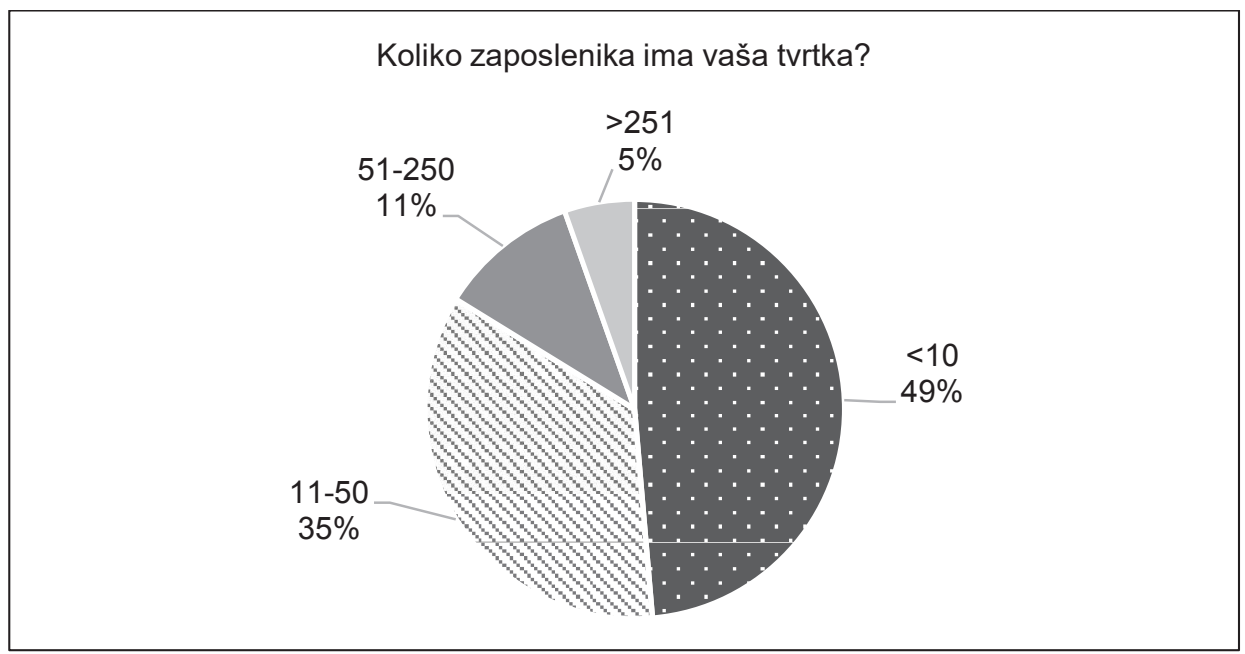

Izvor: Istraživanje

S obzirom na broj godina poslovanja, u istraživanju su sudjelovala poduzeća koja su na tržištu prisutna od 3 do 21 godine. Medijan za broj godina poslovanja iznosi 12, što znači da polovica poduzeća koja su sudjelovala u istraživanju posluju duže od 12 godina.

\subsubsection{Usmjerenost na izgradnju marke}

Rezultati istraživanja pokazuju da većina poduzeća koja pružaju poslovne usluge ima jasno definiran identitet marke i njezino obećanje, odnosno zna što marka njihove usluge predstavlja (81\%). $67 \%$ poduzeća potvrđuje da u razvoju i osnaživanju marke svoje usluge koriste sve marketinške aktivnosti. Čak $87 \%$ uslužnih 
poduzeća marku svoje usluge smatra vrijednom imovinom i strateškim resursom, a njih $63 \%$ navodi da kontrolira vrijednost marke. Dodatno, $65 \%$ poduzeća sve poslovne odluke procjenjuju s obzirom na njihov utjecaj na marku. Konačno, u čak $87 \%$ poduzeća uprava sudjeluje u razvoju marke (Tablica 1.).

Tablica 1.

\section{USMJERENOST PODUZEĆA NA POSLOVNOM TRŽIŠTU USLUGA NA IZGRADNJU MARKE}

\begin{tabular}{|c|c|c|c|c|c|}
\hline Tvrdnja & $\begin{array}{c}\mathrm{U} \\
\text { potpunosti } \\
\text { se ne } \\
\text { slažem }\end{array}$ & $\begin{array}{c}\mathrm{Ne} \\
\text { slažem } \\
\text { se }\end{array}$ & $\begin{array}{l}\text { Niti se } \\
\text { slažem } \\
\text { niti se ne } \\
\text { slažem }\end{array}$ & Slažem se & $\begin{array}{c}\mathrm{U} \\
\text { potpunosti } \\
\text { se slažem }\end{array}$ \\
\hline $\begin{array}{l}\text { U našem poduzeću jasno } \\
\text { znamo što predstavlja } \\
\text { marka naše usluge; njezin } \\
\text { identitet i obećanje jasno su } \\
\text { definirani. }\end{array}$ & $0 \%(0)$ & $2,7 \%$ (1) & $16,2 \%(6)$ & $37,4 \%$ (14) & $43,2 \%(16)$ \\
\hline $\begin{array}{l}\text { Koristimo sve svoje } \\
\text { marketinške aktivnosti kako } \\
\text { bismo razvili marku naše } \\
\text { usluge i učinili je snažnom. }\end{array}$ & $0 \%(0)$ & $8,1 \%(3)$ & $24.3 \%$ (9) & $43,2 \%(16)$ & $24,3 \%$ (9) \\
\hline $\begin{array}{l}\text { Marka naše usluge vrijedna } \\
\text { je imovina i strateški resurs } \\
\text { koji kontinuirano razvijamo } \\
\text { i štitimo na najbolji mogući } \\
\text { način. }\end{array}$ & $0 \%(0)$ & $5,4 \%(2)$ & $8,1 \%$ (3) & $48,6 \%$ (18) & $37,8 \%$ (14) \\
\hline $\begin{array}{l}\text { Vrijednost marke usluge } \\
\text { kontrolni je element u } \\
\text { našem poduzeću. }\end{array}$ & $2,7 \%$ (1) & $8,1 \%(3)$ & $27 \%(10)$ & $40,5 \%(15)$ & $21,6 \%(8)$ \\
\hline $\begin{array}{l}\text { Za razvoj naše marke nije } \\
\text { zadužena samo mala grupa } \\
\text { ljudi u poduzeću, već se } \\
\text { time bavi i uprava. }\end{array}$ & $0 \%(0)$ & $5,4 \%(2)$ & $8,1 \%$ (3) & $18,9 \%(7)$ & $67,6 \%(25)$ \\
\hline $\begin{array}{l}\text { Sve poslovne odluke } \\
\text { procjenjuju se s obzirom na to } \\
\text { kako utječu na marku. }\end{array}$ & $5,4 \%(2)$ & $8,1 \%(3)$ & $21,6 \%(8)$ & $40,5 \%(15)$ & $24,3 \%$ (9). \\
\hline
\end{tabular}

Izvor: Istraživanje 
Na temelju analize ovih rezultata može se odgovoriti na prvo istraživačko pitanje, odnosno zaključiti kako hrvatska poduzeća koja pružaju poslovne usluge jesu usmjerena na izgradnju marke svoje usluge.

\subsubsection{Interno komuniciranje}

Distribucija uslužnih poduzeća koja posluju na poslovnim tržištima prema elementima internog prenošenja marke usluge pokazuje da je važnost takvog internog komuniciranja u hrvatskim uslužnim poduzećima prepoznata.

Konkretno, 70\% (26) poduzeća slaže se i u potpunosti slaže s izjavom da je temelj privrženosti zaposlenika marki usluge posljedica sličnosti njihovih osobnih vrijednosti s vrijednostima koje njihova marka predstavlja. Potom, $81 \%$ (30) poduzeća slaže se i u potpunosti slaže da njihovi zaposlenici razumiju koristi koje klijent ima od njihove marke, a čak $84 \%$ (31) smatra da je većina zaposlenika svjesna kako njihova marka značajno doprinosi cjelokupnom uspjehu poduzeća. Da zaposlenici osobno shvaćaju loše vijesti o marki i ponose se njezinim uspjehom potvrdilo je 68\% (25) poduzeća. Isti rezultati dobiveni su i za izjavu da vrijednosti marke utječu na svakodnevno ponašanje zaposlenika. Kada uzmemo u obzir da je $65 \%$ (24) poduzeća izjavilo da se slaže i u potpunosti slaže s tim da su zaposlenici informirani o vrijednostima koje marka predstavlja i 62\% (23) da zaposlenici žive vrijednosti marke, možemo zaključiti kako su hrvatska poduzeća koje pružaju poslovne usluge svjesna uloge zaposlenika u izgradnji uspješne marke usluge (Tablica 2.). 
Tablica 2.

\section{INTERNO KOMUNICIRANJE MARKE U HRVATSKIM USLUŽNIM PODUZEĆIMA NA POSLOVNOM TRŽIŠTU}

\begin{tabular}{|c|c|c|c|c|c|}
\hline Tvrdnja & $\begin{array}{c}\mathrm{U} \\
\text { potpunosti } \\
\text { se ne } \\
\text { slažem }\end{array}$ & $\begin{array}{c}\text { Ne slažem } \\
\text { se }\end{array}$ & $\begin{array}{l}\text { Niti se } \\
\text { slažem } \\
\text { niti se ne } \\
\text { slažem }\end{array}$ & Slažem se & $\begin{array}{l}\mathrm{U} \\
\text { potpunosti } \\
\text { se slažem }\end{array}$ \\
\hline $\begin{array}{l}\text { Većina naših zaposlenika } \\
\text { dobro je informirana o vri- } \\
\text { jednostima koje predstavlja } \\
\text { naša marka usluge. }\end{array}$ & $0 \%(0)$ & $8,1 \%(3)$ & $27 \%(10)$ & $21,6 \%(8)$ & $43,2 \%$ (16) \\
\hline $\begin{array}{l}\text { Većina zaposlenika našeg } \\
\text { poduzeća razumije i „,̌ivi““ } \\
\text { vrijednosti naše marke } \\
\text { usluge. }\end{array}$ & $0 \%(0)$ & $13,5 \%(5)$ & $24,3 \%$ (9) & $35,1 \%(13)$ & $27 \%(10)$ \\
\hline $\begin{array}{l}\text { Zaposlenici našeg poduzeća } \\
\text { ponose se uspjehom naše } \\
\text { marke i svaku lošu vijest o } \\
\text { marki shvaćaju osobno. }\end{array}$ & $0 \%(0)$ & $8,1 \%(3)$ & $24,3 \%$ (9) & $40,5 \%(15)$ & $27 \%(10)$ \\
\hline $\begin{array}{l}\text { Privrženost zaposlenika } \\
\text { našoj marki temelji se, } \\
\text { prije svega, na sličnostima } \\
\text { njihovih osobnih vrijednosti } \\
\text { s vrijednostima koje naša } \\
\text { marka predstavlja. }\end{array}$ & $0 \%(0)$ & $13,5 \%(5)$ & $16,2 \%(6)$ & $37,8 \%(14)$ & $32,4 \%(12)$ \\
\hline $\begin{array}{l}\text { Vrijednosti koje predstavlja } \\
\text { naša marka više su od riječi, } \\
\text { one utječu na svakodnevno } \\
\text { ponašanje naših zaposlenika. }\end{array}$ & $5,4 \%(2)$ & $10,8 \%$ (4) & $16,2 \%(6)$ & $37,8 \%(14)$ & $39,7 \%$ (11) \\
\hline $\begin{array}{l}\text { Većina zaposlenika našeg } \\
\text { poduzeća razumije kako } \\
\text { naši klijenti mogu imati } \\
\text { koristi od naše marke. }\end{array}$ & $0 \%(0)$ & $0 \%(0)$ & $18,9 \%(7)$ & $43,2 \%(16)$ & $37,8 \%(14)$ \\
\hline $\begin{array}{l}\text { Većina zaposlenika našeg } \\
\text { poduzeća svjesna je kako } \\
\text { marka našeg poduzeća } \\
\text { značajno doprinosi } \\
\text { cjelokupnom uspjehu } \\
\text { poduzeća. }\end{array}$ & $0 \%(0)$ & $2,7 \%(1)$ & $13,5 \%(5)$ & $43,2 \%(16)$ & $40,5 \%$ (15) \\
\hline
\end{tabular}

Izvor: Istraživanje 
Drugo istraživačko pitanje odnosilo se na praksu prenošenja marke usluge zaposlenicima. Iz prethodno analiziranih odgovora ispitanika može se zaključiti da hrvatska poduzeća koja pružaju poslovne usluge aktivno uključuju zaposlenike u izgradnju svoje marke.

\subsubsection{Eksterno komuniciranje}

Rezultati istraživanja upućuju na to da poduzeća prenose informacije o svojoj marki integriranim aktivnostima, odnosno kombinacijom različitih komunikacijskih metoda. Naime, distribucija podataka pokazuje da se 65\% (24) poduzeća slaže i u potpunosti slaže da izričitu pažnju posvećuju integraciji različitih komunikacijskih metoda, a $81 \%$ (30) da njihov štand na događanjima odražava njihovu marku. Da su iskustva drugih klijenata važan element u izgradnji snage marke usluge smatra $70 \%$ (26) poduzeća, koji su izjavili da se slažu i u potpunosti slažu s tim. Zanimljivo je kako se $17 \%$ (6) poduzeća ne slaže i u potpunosti ne slaže s tim da su studije slučaja drugih klijenata važan element izgradnje marke usluge. Nešto više od polovice (57\%) hrvatskih poduzeća koja pružaju poslovne usluge dio budžeta ulažu u vizualno predstavljanje marke, dok je 6\% (2) onih koje se ne slažu i u potpunosti ne slažu s ovom izjavom. U istom postotku (57\%) poduzeća potvrđuju da često pripremaju promotivne materijale za potencijalne klijente. S druge strane, njih gotovo trećina se s ovom tvrdnjom ne slaže (Tablica 3.). 
Tablica 3.

\section{EKSTERNO PRENOŠENJE MARKE U HRVATSKIM USLUŽNIM PODUZEĆIMA NA POSLOVNOM TRŽIŠTU}

\begin{tabular}{|c|c|c|c|c|c|}
\hline Tvrdnja & $\begin{array}{c}\mathrm{U} \\
\text { potpunosti } \\
\text { se ne } \\
\text { slažem } \\
\end{array}$ & $\begin{array}{c}\text { Ne slažem } \\
\text { se }\end{array}$ & $\begin{array}{c}\text { Niti se } \\
\text { slažem } \\
\text { niti se ne } \\
\text { slažem }\end{array}$ & Slažem se & $\begin{array}{c}\mathrm{U} \\
\text { potpunosti } \\
\text { se slažem }\end{array}$ \\
\hline $\begin{array}{l}\text { U svim oblicima } \\
\text { komuniciranja naše } \\
\text { marke pažnju izričito } \\
\text { posvećujemo integraciji } \\
\text { različitih komunikacijskih } \\
\text { metoda. }\end{array}$ & $0 \%(0)$ & $2,7 \%(1)$ & $32,4 \%$ (12) & $40,5 \%(15)$ & $24,3 \%$ (9) \\
\hline $\begin{array}{l}\text { Prilikom sudjelovanja } \\
\text { na događanjima, poput } \\
\text { konferencija i sajmova, } \\
\text { brinemo o tome da naš } \\
\text { štand odražava našu } \\
\text { marku. }\end{array}$ & $0 \%(0)$ & $0 \%(0)$ & $18,9 \%(7)$ & $24,3 \%$ (9) & $\begin{array}{l}56,8 \% \\
(21)\end{array}$ \\
\hline $\begin{array}{l}\text { Dio marketinškog } \\
\text { budžeta ulažemo i u } \\
\text { vizualno predstavljanje } \\
\text { naše marke usluge. }\end{array}$ & $2,7 \%(1)$ & $2,7 \%(1)$ & $18,9 \%(7)$ & $18,9 \%(7)$ & $\begin{array}{l}56,8 \% \\
(21)\end{array}$ \\
\hline $\begin{array}{l}\text { Često pripremamo } \\
\text { promotivne materijale } \\
\text { namijenjene } \\
\text { potencijalnim klijentima. }\end{array}$ & $5,4 \%(2)$ & $24,3 \%$ (9) & $13,5 \%(5)$ & $18,9 \%(7)$ & $\begin{array}{l}37,8 \% \\
(14)\end{array}$ \\
\hline $\begin{array}{l}\text { Studije slučaja (iskustva/ } \\
\text { izjave naših klijenata/ } \\
\text { testimoniali) vrlo su važan } \\
\text { element za izgradnju } \\
\text { snage naše marke. }\end{array}$ & $2,7 \%(1)$ & $13,5 \%(5)$ & $13,5 \%(5)$ & $24,3 \%$ (9) & $\begin{array}{l}45,9 \% \\
(17)\end{array}$ \\
\hline
\end{tabular}

Izvor: Istraživanje

Ime i logo tvrtke elementi su marke usluge kod 87\% (32) uslužnih poduzeća. Naziv usluge element je marke kod 67\% (25) uslužnih poduzeća, a kod 49\% (18) i slogan. Logo usluge kao element izgradnje marke ima $49 \%$ (18) uslužnih poduzeća, dok ime vlasnika kao element izgradnje marke koristi tek 19\% (7) uslužnih poduzeća (Graf 3). 
Graf 3.

ELEMENTI MARKE USLUGE USLUŽNIH PODUZEĆA NA POSLOVNOM TRŽIŠTU (VIŠESTRUKI ODGOVORI)

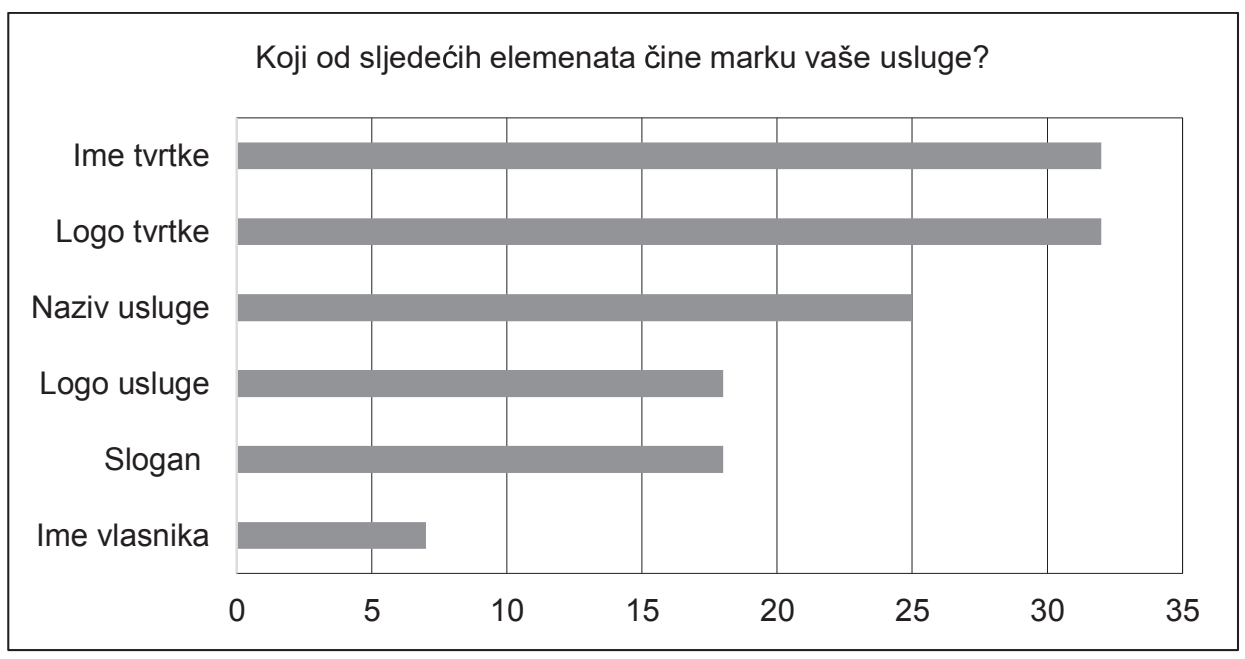

Izvor: Istraživanje

Naposljetku, treće istraživačko pitanje imalo je za cilj saznati vode li hrvatska poduzeća koja pružaju poslovne usluge računa o dosljednosti prilikom prenošenja svoje marke usluge. Na osnovu rezultata pitanja iz dijela ankete usmjerenog na istraživanje eksternog komuniciranja marke usluge, može se zaključiti kako poduzeća vode računa o dosljednosti prilikom prenošenja svoje marke usluge. Štoviše, vidljivo je kako većina hrvatskih poduzeća koja pružaju poslovne usluge primjenjuju holistički pristup izgradnji marke usluge.

\subsection{Ograničenja istraživanja}

Prilikom tumačenja nalaza valja uzeti u obzir ograničenja provedenog istraživanja. Predstavljeni rezultati proizlaze iz mišljenja 37 hrvatskih poduzeća koja pružaju usluge na poslovnim tržištima i koja su prihvatila poziv za sudjelovanje $\mathrm{u}$ istraživanju. Za generalizaciju zaključaka bilo bi potrebno povećati uzorak te ga strukturom (godine poslovanja, industrija, veličina mjerena brojem zaposlenih) 
učiniti reprezentativnim za čitavu populaciju. Veličina uzorka posljedica je teške dostupnosti uzorka koja zahtjeva poznavanje osobe i dostupnost kontakta, što je čest istraživački problem u području marketinga poslovnih tržišta (za razliku od tržišta krajnje potrošnje). Osim toga, veličina uzorka posljedica je i odbijanja znatnog broja poduzeća koja su odgovarala odabranom uzorku da sudjeluju u istraživanju. Za pretpostaviti je, također, da su na istraživanje pristala poduzeća koja svoju praksu smatraju „dobrom“, što u određenoj mjeri utječe na objektivnost rezultata, odnosno može sugerirati određenu pristranost prilikom njihova tumačenja.

U radu je korištena deskriptivna statistika, što je primjereno naravi podataka i prirodi eksplorativnog istraživanja. U budućim istraživanjima mogle bi se istražiti neke druge varijable i primijeniti njima odgovarajuće složenije statističke metode.

Konačno, ovo je istraživanje slijedilo logiku prethodno provedenih istraživanja. U sljedećim bi istraživanjima bilo zanimljivo istražiti i suvremene oblike komuniciranja putem društvenih mreža, posebice onih specijaliziranih za potrebe poslovnih korisnika (LinkedIn i Twitter), kao i ulogu utjecajnih osoba (engl. influencer) koje predstavljaju važan element potpore markama i na tržištima krajnje i na tržištima poslovne potrošnje. Juntunen, Ismaiglova i Oikarinen (2020) naglašavaju kako uloga društvenih medija u marketingu poslovnih tržišta privlači sve više pažnje istraživača, osobito u području upravljanja sadržajem na društvenim medijima (Taiminen i Ranaweera, 2019).

\section{RASPRAVA}

Nalazi istraživanja ukazuju na to da je više od polovice analiziranih poduzeća koja pružaju usluge na tržištima poslovne potrošnje (engl. business-to-business) usmjereno na izgradnju marke. To se može zaključiti iz činjenice da se minimalno $63 \%$, odnosno 23 od 37 poduzeća koja su sudjelovala u istraživanju, slaže i u potpunosti slaže s izjavama iz ove grupe pitanja. Većina poduzeća iz uzorka navodi kako imaju definiran identitet i obećanje svoje marke usluge. Do sličnih su nalaza došli i Marquardt, Golic i Davis (2011), koji su naglasili da poduzeća trebaju razviti neodoljive i jedinstvene vrijednosti koje će se povezivati s njihovom markom usluge. Nadalje, $67 \%$, odnosno 25 od 37 poduzeća koja su sudjelovala u istraživanju, potvrđuje da u razvoju i osnaživanju marke svoje usluge koriste sve marketinške aktivnosti, što je u skladu s preporukama iz prethodnih istraživanja prema kojima uslužna poduzeća trebaju odrediti resurse koji će osigurati dosljedno i željeno iskustvo klijenta te uložiti u interno i eksterno prenošenje vrijednosti svoje marke (Marquardt, Golic i Davis, 2011). 
Segment pitanja koji se odnosi na interno komuniciranje pokazuje kako hrvatska poduzeća koja pružaju usluge na poslovnim tržištima nastoje što bolje interno prenositi marku usluge. Najmanje $62 \%$ poduzeća slaže se i u potpunosti slaže s izjavama iz ove grupe pitanja. Istraživanje iz 2019. godine koje su proveli Biedenbach, Hulten i Tarnovskaya također ukazuje na to kako je interni marketing ključna determinanta izgradnje marke na poslovnim tržištima i da je razvoj ljudskih potencijala strateško ulaganje za tvrtke koje žele povećati vrijednost svoje marke usluge. Na slično su uputili Zhank, Jiang, Shabbir i Zhu (2016), čiji rezultati pokazuju kako su interna komunikacija i obučavanje zaposlenika ključni elementi internog marketinga koji posljedično rezultiraju koordiniranijim pristupom pružanju usluga klijentima i iskustvu koje klijent ima s poduzećem.

Dio izjava kojima se istražuje eksterno prenošenje marke usluge hrvatskih poduzeća koje pružaju usluge na poslovnim tržištima pokazuju kako su ime tvrtke i logo tvrtke najčešći elementi marke usluge koji se prenose kroz različite kanale. Isto je pokazalo i istraživanje koje su proveli Marquardt i suradnici 2011. godine - ime i logo tvrtke najvažniji su prvi koraci u izgradnji prepoznatljivosti poduzeća i općenito njegove vidljivosti. Dosljedno prenošenje vrijednosti marke različitim komunikacijskim kanalima pomaže poduzećima da bolje odašilju poruku svoje marke i tako izgrade uspješne marke usluga na poslovnim tržištima, zaključak je istraživanja koje su proveli Zhank i suradnici (2016) i Marquardt i suradnici (2011). Zhank i suradnici (2016) naglašavaju kako su preporuke drugih klijenata ključne za izgradnju marke za poduzeća koja se bave pružanjem usluga, što rezultati ovog istraživanja ne potvrđuju. Većina hrvatskih poduzeća koja pružaju poslovne usluge dio budžeta ulaže u vizualno predstavljanje marke te priprema promotivne materijale za potencijalne klijente. Marquardt i suradnici (2011) ističu kako se uslužne tvrtke najbolje diferenciraju ako se usredotoče na pružanje karakterističnog iskustva koje klijent može ostvariti samo s njihovom markom i da je upravo promoviranje iskustava drugih klijenata najučinkovitiji alat izgradnje marke usluge. Stoga onaj manji dio ispitanih poduzeća koji ne priprema promotivne materijale i ne koristi iskustva drugih klijenata za izgradnju marke usluge treba ove preporuke uzeti u obzir.

\section{ZAKLJUČAK}

Bez obzira na to koju strategiju i elemente marke usluge poduzeće izabralo, važno je primijeniti holistički pristup razvoju marke kako bi svi komunikacijski kanali i materijali dosljedno prenosili marku usluge i njene poruke. U konačnici, holistički pristup rezultira velikom prepoznatljivošću marke, čak i kada se jedan element prenosi odvojeno. 
S ciljem saznanja kakva je praksa hrvatskih poduzeća koja pružaju usluge na poslovnim tržištima u izgradnji marke usluge provedeno je istraživanje u kojem je sudjelovalo 37 poduzeća. Istraživanje je pokazalo da su analizirana poduzeća svjesna važnosti marke svoje poslovne usluge i činjenice da marka može steći određenu vrijednost. Ispitanici iz analiziranih poduzeća navode kako marku tretiraju kao vrijednu nematerijalnu imovinu i vode računa o tome kako poslovne odluke utječu na nju. Utvrđeno je, također, kako analizirana poduzeća provode aktivnosti internog komuniciranja i nastoje zaposlenike što više uključiti u stvaranje vrijednosti marke. Štoviše, više su usmjerene na interno prenošenje marke u usporedbi s eksternim. Na temelju istraživanja može se zaključiti kako većina poduzeća iz uzorka primjenjuje holistički pristup u izgradnji marke i koristi strategiju korporativne marke. Slične rezultate pokazala su i istraživanja korištena kao okvir istraživanja ovog rada.

S obzirom na to da je područje marki usluga na poslovnim tržištima, u usporedbi s markama usluga na tržištima krajnje potrošnje, manje istraženo, ovaj rad predstavlja doprinos tom području i dobru osnovu za daljnja istraživanja ovog područja.

\section{POPIS LITERATURE}

1. Aaker D.A., Kumar V., i Dej Dž.S.(2008). Marketinško istraživanje. Beograd: Ekonomski fakultet Beograd

2. Aspara, J., i Tikkanen, H. (2008). Significance of corporate brand for business-to-business companies. The Marketing Review, 8 (1), 43-60. Dostupno na https://www.ingentaconnect.com/contentone/westburn/ tmr/2008/00000008/00000001/art00004

3. Balmer, J. M. T., Lin, Z., Chen, W., i He, X. (2020). The role of corporate brand image for B2B relationships of logistics service providers in China. Journal of Business Research, 117, str. 850-861. Dostupno na https://www. sciencedirect.com/science/article/pii/S0148296320302022

4. Bals, L., Hartmann, E., Ritter, Th., (2009). Barriers of purchasing departments' involvement in marketing service procurement. Industrial Marketing Management, 38(8), 892-902. Dostupno na https://www.sciencedirect.com/ science/article/abs/pii/S0019850109001357

5. Baumgarth, C. i Schmidt, M. (2010). How strong is the business-to-business brand in the workforce? An empirically-tested model of 'internal brand equity' in a business-to-business setting. Industrial Marketing Management, 39 
(8), 1250-1260. Dostupno na https://www.sciencedirect.com/science/article/ abs/pii/S0019850110000337

6. Bengtsson, A. i Servais, P. (2005). Co-branding on industrial markets. Industrial Marketing Management, 34 (7), 706-713. Dostupno na https:// www.sciencedirect.com/science/article/pii/S001985010500088X

7. Bendixen, M., Bukasa, K. i Abratt, R. (2004). Brand equity in the business-to-business market. Industrial Marketing Management, 33 (5), 371380. Dostupno na https://www.sciencedirect.com/science/article/abs/pii/ S0019850103001226

8. Beverland, M., Napoli, J. i Yakimova, R. (2007). Branding the business marketing offer: exploring brand attributes in business markets. Journal of Business and Industrial Marketing, 22 (6), 394-399. Dostupno na https:// www.emerald.com/insight/content/doi/10.1108/08858620710780154/full/ html

9. Biedenbach, G., Hulten, P. i Tarnovskaya, V. (2019). B2B brand equity: investigating the effects of human capital and relational trust. Journal of Business \& Industrial Marketing, 34 (1), 1-11. Dostupno na https://www.emerald.com/ insight/content/doi/10.1108/JBIM-01-2018-0003/full/html

10. Blombäck, A. i Axelsson, B. (2007). The role of corporate brand image in the selection of new subcontractors. Journal of Business and Industrial Marketing, 22 ( 6), 418-430. Dostupno na https://www.emerald.com/insight/ content/doi/10.1108/08858620710780181/full/html

11. Coleman, D. A., de Chernatony, L. i Christodoulides, G. (2011). B2B service brand identity: Scale development and validation. Industrial Marketing Management, 40 (7), str. 1063-1071. Dostupno na https://www.sciencedirect. com/science/article/abs/pii/S0019850111001386

12. Diba, H., Vella, J. M., i Abratt, R. (2019). Social media influence on the B2B buying process. The Journal of Business and Industrial Marketing, 34(7), str. 1482-1496. Dostupno na https://search.proquest.com/docview/2301344803/ab stract $/ 6 \mathrm{~A} 27111593 \mathrm{~B} 641 \mathrm{FCPQ} / 10$ ?accountid $=132154$

13. Gomes, M., Fernandes, T. i Brandão, A. (2016). Determinants of brand relevance in a B2B service purchasing context. Journal of Business \& Industrial Marketing, 31 (2), str. 193-204. Dostupno na https://www.emerald.com/insight/content/doi/10.1108/JBIM-08-2014-0151/full/html

14. Grbac, B. (2007). Načela marketinga. Rijeka: EFRI

15. Guenther, M. i Guenther, P. (2019). The value of branding for B2B service firms - The shareholders' perspective. Industrial Marketing Management, 78, str. 88-101. Dostupno na https://www.sciencedirect.com/science/article/ abs/pii/S0019850117301621?via\%3Dihub 
16. Juntunen, M., Ismagilova, E. i Oikarinen, E. (2020). B2B brands on Twitter: Engaging users with a varying combination of social media content objectives, strategies, and tactics, Industrial Marketing Management, 89, str. 630-641. Dostupno na https://www.sciencedirect.com/science/article/pii/ S0019850118301834

17. Keller, K.L. (2003, 2013).Strategic Brand Management: Building Measuring and Managing Brand Equity, 4. ed. New Jersey: Pearson Prentice-Hall

18. Kotler P. i Keller K. L. (2006). Marketing menadžment. Beograd: Data status

19. Kotler, P. i Keller, K.L. (2008). Upravljanje marketingom. Zagreb: Mate

20. Kotler, P. i Pfoertsch, W. (2007). Being known or being one of many: the need for brand management for business-to-business (B2B) companies. Journal of Business and Industrial Marketing, 22 (6), 357-362. Dostupno na https:// www.emerald.com/insight/content/doi/10.1108/08858620710780118/full/ html

21. Kotler, P. i Pfoertsch, W. (2006). B2B brand management. Berlin: Springer Berlin Heidelberg

22. Leek, S. i Christodoulides, G. (2011). A literature review and future agenda for B2B branding: challenges of branding in a B2B context. Industrial Marketing Management, 40 (6), 830-837. Dostupno na https://www.sciencedirect.com/science/article/abs/pii/S0019850111000654

23. Lynch, J. i de Chernatony, L. (2004). The power of emotion: Brand communication in business-to-business markets. Journal of Brand Management, 11 (1), 403-419. Dostupno na https://link.springer.com/article/10.1057/palgrave. bm. 2540185

24. Marquardt, A., Golicic, S. i Davis, D. (2011). B2B services branding in the logistics services industry.Journal of Services Marketing,25(1),47-57.Dostupno na https://www.emerald.com/insight/content/doi/10.1108/08876041111107050/ full/html

25. Mudambi, S. (2002). Branding importance in business-to-business markets: three buyer clusters. Industrial Marketing Management, 31 (6), 525533. Dostupno na https://www.sciencedirect.com/science/article/abs/pii/ S0019850102001840

26. Muylle, S., Dawar, N. i Rangarajan, D. (2012). B2B Brand Architecture. California Management Review, 54 (2), 58-71. Dostupno na https://journals. sagepub.com/doi/abs/10.1525/cmr.2012.54.2.58

27. Pemer, F., Werr, A. i Bianchi, M. (2014). Purchasing professional services: A transaction cost view of the antecedents and consequences of purchasing formalization. Industrial Marketing Management, 43, 840-849. Dostupno na https://www.sciencedirect.com/science/article/abs/pii/S0019850114000467 
28. Roberts, J. i Merrilees, B. (2007). Multiple roles of brands in business-to-business services. Journal of Business \& Industrial Marketing, 22 (6), 410-417. Dostupno na https://www.emerald.com/insight/content/ doi/10.1108/08858620710780172/full/html

29. Sammy, M.,K., Omwenga, J.i Iravo, M.(2016). Effects of Service Brand Identity Building on Brand Performance in the Insurance Sector of Kenya. Journal of Marketing and Consumer Research, 24 (1), 97-111. Dostupno na https://www. semanticscholar.org/paper/Effects-of-Service-Brand-Identity-Building-onBrand-Sammy-Omwenga/ea371292ba42f3cfd061f167d8c6e7871a71bad8

30. Sharp, B. (1996). Brand Equity and Market-based Assets of Professional Service Firm. Journal of Professional Services Marketing USA, 13 (1), 3-13. Dostupno na https://www.tandfonline.com/doi/abs/10.1300/J090v13n01_02

31. Sinčić, D. (2004). Marketing poslovnih tržišta u, Previšić, J., Ozretić Došen, Đ. (Ur.), Marketing (str. 415-440). Zagreb: Adverta,

32. Sinčić Ćorić, D., Anić, I., Piri Rajh, S., Rajh, E., Kurnoga, N. (2017). Organizational buying decision approaches in manufacturing industry: developing measures and typology. Journal of Business \& Industrial Marketing, 32(2), 227-237. Dostupno na https://www.emerald.com/insight/ content/doi/10.1108/JBIM-10-2014-0214/full/html

33. Srivastava, K. i Sharma, N. (2013). Service quality, corporate brand image, and switching behavior: the mediating role of customer satisfaction and repurchase intention. Services Marketing Quarterly, 34 (4), 274-291. Dostupno na https://www.tandfonline.com/doi/abs/10.1080/15332969.2013.827020

34. Taiminen, K. i Ranaweera, C. (2019). Fostering brand engagement and valueladen trusted B2B relationships through digital content marketing: The role of brand's helpfulness. European Journal of Marketing, 53(9), str. 1759-1781. Dostupno na https://www.emerald.com/insight/content/doi/10.1108/EJM-102017-0794/full/html

35. Tomašević Lišanin, M., Kadić-Maglajić, S. i Drašković, N. (2019.).Principi prodaje i pregovaranja. Zagreb: Ekonomski fakultet - Zagreb

36. Verster, A., Petzer, D.J. i Cunningham, N. (2019). Using brand identity to build brand equity: A comparison between the South African and Dutch business-to-business architectural industry. South African Journal of Business Management, 50 (1), 1-12. Dostupno na https://www.researchgate.net/publication/332624033_Using_brand_identity_to_build_brand_equity_A_comparison_between_the_South_African_and_Dutch_business-to-business_architectural_industry

37. Vranešević, T. (2007). Upravljanje markama (Brand Management). Zagreb: Accent 
38. Zhang, J., Jiang, Y., Shabbir, R., i Zhu, M. (2016). How brand orientation impacts B2B service brand equity? An empirical study among Chinese firms. Journal of Business \& Industrial Marketing, 31 (1), 83-98. Dostupno na https://www.emerald.com/insight/content/doi/10.1108/JBIM-02-2014-0041/ full/html?skipTracking=true

\section{RESEARCH OF THE DEVELOPMENT AND MANAGEMENT OF BUSINESS SERVICE BRANDS IN CROATIAN COMPANIES}

Summary

This paper analyses the development and management of business service brands. After the theoretical part, the results of the primary research are presented. The aim of the research is to find out how enterprises in Croatia develop and manage their business service brands and how they communicate and evaluate them. An ad hoc cross-sectional research was conducted on a convenient sample of enterprises providing different business services. The results show that the analysed enterprises treat their service brands as a valuable intangible asset, that they apply a holistic approach in brand building, and mostly use the corporate brand strategy. The inseparability of the service from employees results in the fact that Croatian enterprises are more focused on internal than on external communication. Since the area of development and management of business services brands is less investigated in literature than consumer services brands, the paper contributes to the body of knowledge of business services brands in. general. Moreover, the conclusions grounded in research results represent a valuable input for enterprises aiming to actively manage their business service brand.

Keywords: business service brand, business markets, service brand identity, service brand value, corporate brand 